\title{
Oil Price Shocks, Agriculture and Household Welfare in Nigeria: Results From an Economy-Wide Model
}

\author{
Nkang M. Nkang, PhD ${ }^{15}$ \\ Research Department, Central Bank of Nigeria, Abuja - Nigeria
}

Doi:10.19044/esj.2018.v14n31p158 URL:http://dx.doi.org/10.19044/esj.2018.v14n31p158

\begin{abstract}
Following the recent plunge in the price of crude oil in the international market and its attendant implications on oil-exporting countries, this paper simulated the impact of a fifty per cent decline in world oil price on agriculture and household welfare using a general equilibrium model, and data from a social accounting matrix (SAM) for Nigeria. Results show that gross domestic output and supply of composites in the agriculture sectors increased substantially, causing agriculture prices to decline. Furthermore, the shock reduced incomes/expenditure in all household groups except urban-north households that recorded an increase. We therefore conclude that lower oil prices may not necessarily lead to output losses, but could boost output in other sectors, engendering diversification of the export base. Also, targeted interventions would prove more effective in mitigating the negative impact of oil price shocks on households than general palliative measures based on the results of the study.
\end{abstract}

Keywords: Oil price, shocks, agriculture, Nigeria households, simulations, Income, general equilibrium

\subsection{INTRODUCTION}

More than production, crude oil price is a key variable in the global oil market. Changes in crude oil prices could have huge impacts on oil-importing and exporting countries, alike at both the macro and micro levels. At the macro-level, sudden changes in oil prices affect macroeconomic variables such as exchange rate, interest rate, and inflation and could lead to fluctuations in current account balance and net foreign assets position, leading to a recession or economic growth (Thomas, et al., 2010).

\footnotetext{
${ }^{15}$ Nkang M. Nkang is a Principal Manager (Economist) with the Research Department, Central Bank of Nigeria. The views expressed in this paper are those of the author and do not in any way reflect those of the Bank or its Policy.
} 
Similarly, at the micro-level, the macroeconomic outcomes of a sudden oil price change could have far-reaching distributional impacts on individuals, households and various segments of the population via three major effects. These include the endowment effect (which reflect changes in the quantum of resources available to the individual), price effect (reflecting changes in the reward of the resource endowments) and occupational effects (which are linked to changes in resource allocation) (Essama-Nssah, et al., 2008).

Nigeria is a net producer/exporter of crude oil ranking $8^{\text {th }}$ in the OPEC and $12^{\text {th }}$ largest producer of oil in the world. Nigeria's economy depends on revenues from the export of crude oil, which constitutes about 70 per cent of export earnings; over 70 per cent of government revenue and 10.45 per cent of GDP (OPEC, 2015; NBS, 2015a; NBS, 2015b). Given its huge reliance on proceeds from oil exports, the Nigerian economy is highly vulnerable to oil price shocks. Consequently, a small change in oil price, be it a rise or fall, can have a large impact on the economy. For example, Umar and Kilishi (2010) note that a US\$1 increase in oil price in early 1990s increased Nigeria's foreign exchange earnings by about US\$650 million (2 per cent of GDP at that time) and its public revenues by US\$320 million a year.

The recent oil price shock of 2014 saw crude oil prices plummeting almost 50 per cent from average of about US\$115 in June 2014 to about US\$57.47 in April 2015, and even as low as US\$30.66 in January, 2016. This had led to lower export earnings and low accretion to external reserves; substantial capital outflows particularly from portfolio investments; depreciation of the exchange rate from an average of $\$ 157.29 / \mathrm{US} \$$ in June 2014 to an all-time high of $\$ 525 /$ US\$ in September 2016 leading to a loss in real incomes and purchasing power, especially for imported goods and services.

From the foregoing therefore, the oil price shock would have impacted not only the macro-economy but also specific sectors and households in different ways. Many studies that have assessed the impact of oil price shocks in Nigeria have always focused on the effect on macroeconomic variables of interest (see, for example, Alley et al., 2014; Akinyele and Ekpo, 2013; Adeniyi et al., 2011; Iwayemi and Fowowe, 2010; Mordi and Adebiyi, 2010; Olusegun, 2008). Those that have assessed the impact at the micro level are scarce. Thus, this paper examines the impact of an oil price shock on agriculture (as a dominant employment sector) and the welfare of Nigerian households within a general equilibrium framework, considering the strong link between households' wellbeing and the agriculture sector in Nigeria.

The remainder of the paper is structured in four parts. Section 2 presents the literature review covering theoretical issues and related empirical studies. Section 3 is concerned with the methodology; it describes the data and 
the framework for analysis. The results are presented and discussed in section 4 while the last section outlines the policy implications and conclusions.

\subsection{LITERATURE REVIEW}

The review of literature is presented in two subsections covering theoretical and empirical literature.

\subsection{Theoretical Issues}

A shock is a sudden event beyond the control of economic authorities that has a significant impact on the individual or economy (see, Varangis, et al., 2004). It can either be positive or negative depending on whether its effect is beneficial or detrimental to the individual or economy. At the individual or household level, shocks can cause changes in household income, consumption and/or their capacity to accumulate productive assets. Similarly, shocks can cause fluctuations in national income, output and employment at the economy level.

An oil price shock is an economic shock, which could have a significant impact on the individual or household, as well as, aggregate effects on the economy. The impact of oil price shocks, whether they come through as positive or negative, essentially depends on whether they are studied in the context of an oil exporting or oil importing country. Once this key distinction is made, the impact of the shock on the household, sector or macroeconomic variables/aggregates can best be understood through their transmission channels.

Generally, the key transmission mechanisms for the impact of oil price shocks to either the micro or macro-economy are changes in prices (relative prices), employment (of labour and capital) and incomes, and changes in government expenditures. There is very strong evidence that these three channels, individually or in combination, are pervasive during a crisis (see, for example, Coffman, et al., 2007; Berument, et al., 2010; Mordi and Adebiyi, 2010).

As earlier indicated, the effect of an oil price shock is different for net oil importers and net oil exporting nations. For net importing countries a shock that increases oil prices could lead to a fall in output growth in many economic sectors, particularly in the industrial and transport sectors, largely due to an increase in energy costs. In addition, the high energy costs could lead to increased production costs, which could cause private investment to fall and could further affect the competitiveness of the oil importing country. Moreover, an oil price shock can affect the balance of payments of the netimporting country through changing terms of trade. The extent of this effect will however depend largely on the share of oil in total imports of the country. 
On the individual and household level, an oil price shock could lead to an increase in food prices as a result of the cost of production of food, like cost of inorganic fertilizers and transportation. Food prices could further increase from this shock due to increased competition for inputs, as a result of the incentive for agriculture and manufacturing to replace crude oil with biofuels, which use crops such as cereals and sugar cane (Mondi et al., 2011).

Furthermore, since the share of households' consumption of food and fuel is significant, high oil prices could bring about substantial inflationary pressures. This is even more so for developing countries, where inflation has been linked to increases in international oil prices and domestic demand pressures. (Rasche and Tatom, 1977; Jiménez-Rodríguez and Sanchez, 2005). Beyond this, the drop in purchasing power as a result of the inflationary pressures and fall in domestic output, in turn weakens domestic demand, which could lead to a fall in the demand for factors of production particularly labour and capital, and thus could worsen unemployment.

For oil exporting countries, one of the main transmission channels for the impact of an oil price shock is through their effect on government revenue and expenditure. This is because most of the oil revenue in these countries is earned by the government. In fact, changes in oil prices are reflected in the expenditure patterns of the government of oil exporting countries. This has translated to procyclical fiscal policy in such countries, in which fluctuations in economic activity intensify in relation to changes in oil prices (Sturm et al., 2009; Cantore, et al., 2012). In spite of the procyclical nature of fiscal policy, there is evidence that while a fall in oil prices leads to economic stagnation in net oil exporting countries, a rise in oil prices does not lead to sustained economic growth. This thus presupposes that the impacts of oil price shocks are asymmetrically linked to fiscal policy, and that transmission mechanisms of positive and negative oil price shocks may be different, due to several factors including poor management and rent-seeking behaviour in the allocation of increased resources during a positive price shock (Mordi and Adebiyi, 2010; Moshiri and Banihashem, 2011). A price increase directly increases real national income through higher export earnings, though part of this gain may be later offset by losses from lower demand for exports generally due to the economic recession suffered by trading partners.

A fall in the price of oil would have profound effects on the government spending, which can affect labour demand, relative prices, direct transfers to households and the provision of public goods and service, which benefit the poor. Oil price changes also entail demand-side effects on consumption and investment. Consumption is affected indirectly through its positive relation with disposable income. Oil price rises reduce the consumers spending power. Investment may also be affected if the oil price shock encourages producers to 
substitute less energy intensive capital for more energy-intensive capital (see, Daniel, 1997; Hamilton, 1996).

Again, if there is a reduction in government spending following a fall in oil prices, inflationary pressures are likely to be low, and depending on the consumption patterns of household categories, some would likely experience an improvement in their real incomes (see, Cashin and Patillo, 2000; Olomola and Adejemo, 2006). However, if inflationary pressures arise as a result of a positive oil price shock, the efficacy of monetary policy in maintaining price stability could constrained. This is particularly due to the inclination of the government to pursue expansionary fiscal policies.

\subsection{Related Empirical Literature}

Although the body of empirical evidence linking oil price shocks with economic outcomes is vast, specific studies for Nigeria relating oil price shocks to agriculture and household welfare are scanty. The scope of this review therefore covers Nigeria and non-Nigerian studies as well as the general impact of oil price shocks.

Alley et al. (2014) examined the impact of oil price shocks on economic growth in Nigeria using annual data from 1981 to 2012 and the Generalised Method of Moments (GMM) for analysis of the data. Their results indicated that oil price shocks impacted economic growth negatively but not significantly. However, positive oil price shocks significantly benefitted oil exporting countries like Nigeria, which was in line with received wisdom. The authors therefore concluded that oil price shocks created uncertainty and undermined effective management of crude oil revenues hence the negative effect of oil price shocks.

Ikram and Waqas (2014) empirically examined the impacts of crude oil price fluctuations on agriculture productivity growth from 1980 to 2003 in Pakistan. The authors made use of co-integration and error-correction technique in analysing annual time-series data for the period. The results of the study indicated that oil prices and excess intake of fertilizer have negative impact on agricultural productivity growth.

Binuomote and Odeniyi (2013) carried out a study to empirically assess the effect of crude oil prices on agricultural Productivity in Nigeria between 1981 and 2010 using annual time series data and the co-integration and error correction technique for analysis. The results of the analysis showed that oil prices in Nigeria during the period were negatively related to agricultural productivity as a 10 per cent increase in oil prices led to a 0.4 and 0.34 per cent fall in agricultural productivity in the short- and long-run respectively. The study concluded that crude oil prices actually had a negative and significant effect on agricultural production in Nigeria. 
Akinyele and Ekpo (2013) studied oil price shocks and Macroeconomic performance in Nigeria using quarterly data which spanned 1973Q1 to 2010Q4 within the VAR framework in order to determine both symmetric and asymmetric impacts of oil price shocks on macroeconomic variables. The main findings of their study indicate that positive oil price shocks have both strong short- and long-run impacts on real GDP, triggering inflation and domestic currency depreciation as imports rise. The findings also reveal that positive oil shocks lead to expansionary fiscal policy stance in the short-term. In conclusion, symmetric shocks do not pose significant inflationary threat to the Nigerian economy but improves the level of GDP in the short-run, while asymmetric effects show that both positive and negative oil price shocks influence real government expenditure in the long-run, among other variables.

Udoh and Eghuaikhide (2012) examined the co-movement and causality relationship between oil price fluctuations and domestic food price inflation in Nigeria for the 1970 to 2008 period. The study analysed annual time-series data for the said period, using tests for stationarity, cointegration and Granger causality as well as multivariate regression. Their results provided evidence in support of a causal relationship between oil price distortions and food price instability in Nigeria. The paper thus, concludes that oil price volatility complements domestic food price inflation in Nigeria.

Assessing the impact of oil price shocks on economic growth in Nigeria, Adeniyi, et al., (2011) used the VAR methodology to analyse quarterly time series data (comprising measures of oil price shock, inflation, real interest rate, real exchange rate) from 1985Q1 to 2008Q4. Their results show that the impact of oil price shocks on most of the macroeconomic variables in Nigeria is very minimal. Specifically, the results confirmed that oil price shocks accounted for less than 1per cent of the variations in output, inflation and government revenue. The authors concluded that although a policy of diversification is usually recommended for economies which depend solely on oil revenue, the applicability of such an option appears unclear in Nigeria based on their findings.

Iwayemi and Fowowe (2010) studied the impact of oil price shocks on selected macroeconomic variables in Nigeria using quarterly time series data spanning 1985Q1 to 2007Q4. Granger-causality tests, impulse response functions, and variance decomposition analysis were used in the analysis of data. The results of their analysis showed that different measures of linear and positive oil shocks did not cause output, government expenditure, inflation, and the real exchange rate. Moreover, the results support the existence of asymmetric effects of oil price shocks as negative oil shocks significantly cause output and the real exchange rate. The study concludes that oil price shocks account only for a small amount of forecast variation for most 
macroeconomic variables in the model. Also, positive oil shocks contributed less than 2 per cent to the variation in most variables with the exception of net exports, where oil shocks accounted for as much as 6per cent of the variation in the variable. Finally, there is evidence of the asymmetric effects of oil shocks as negative oil shocks had a more pronounced effect on the macro economy.

Mordi and Adebiyi (2010) examined the effects of oil price shocks on output and prices in Nigeria. The study used a structural VAR model to analyse the impact of oil price shocks on output and prices based on monthly timeseries data from $1999 \mathrm{M} 1$ to $2008 \mathrm{M} 12$. Their results show that the impact of oil price shocks on output and prices is asymmetric in nature; with the impact of oil price decrease significantly greater than oil price increase. Also, oil price changes play a significant role in determining the variance decompositions of output and prices. Based on the results, the authors concluded that any policy that is aimed at moving the economy forward must focus on price stability in which changes in oil price play a significant role.

Assessing the dynamic relationship between oil production and food insecurity in Nigeria, Akpan (2009) used the VAR methodology to analyse quarterly time-series data from 1970 to 2007 . The result of the analyses showed a decline in food production, occasioned by the neglect of the agricultural sector. It further indicated that high food imports contributed significantly to shocks in food supply but not significantly in determining food security. In conclusion, the study reiterated the need for policies that will enhance domestic production of staple foods and reduce the over dependence on the oil resource in Nigeria.

Olusegun (2008) examined the impact of oil price shocks on the Nigerian economy using annual time series data spanning 1970 to 2005 and the VAR framework to analyse the impact of oil price shocks on several macroeconomic variables (real gross domestic product, consumer price index, real oil revenue, real money supply, real government recurrent expenditure, real government capital expenditure). Results show that oil price shocks significantly contribute to the variability of oil revenue and output, while oil price shock does not have substantial effects on money supply, price level and government expenditure. Further results show that the variability in the price level is explained substantially by output and money supply shocks. The study concludes that oil price shocks have produced a small and modest impact on the money supply, suggesting a limited role of monetary policy in influencing economic activity, making government expenditure the major determinant of the level of economic activity.

The current study differs from the ones reviewed above in terms of both data and methodology used and the questions pursued, as well. Moreover, the studies are not only based on partial equilibrium analyses but also used time- 
series data. Apart from these, most of the studies (Alley et al., 2014; Akinyele and Ekpo, 2013; Adeniyi et al., 2011; Iwayemi and Fowowe, 2010; Mordi and Adebiyi, 2010; Olusegun, 2008) assessed the impact of oil price shocks on either economic growth or other macroeconomic variables (like inflation, government expenditure, real exchange rate, money supply, etc.). Even the few (like, Binuomote and Odeniyi, 2013; Udoh and Eghuaikhide, 2012; Akpan, 2009) that assessed the impact of oil price shocks variously on agriculture productivity growth, food security and domestic food price inflation did not consider its impact on households in terms of welfare. These are the major gaps that the current study attempts to fill. The current study relies on both micro data (from a household survey) and macro data (from a social accounting matrix) to determine the impact of an oil price shock on both agriculture and households welfare using four representative household groups in Nigeria in a general equilibrium framework. This allows us to capture both direct and indirect repercussions of the oil price shock.

\subsection{METHODOLOGY ${ }^{16}$}

\subsection{Data}

The Social Accounting Matrix (SAM) for Nigeria compiled by the International Food Policy Research Institute (IFPRI) in 2010 provided the database used for the computable general equilibrium (CGE) model analysis (see Nwafor, et al., 2010). Generally, sources for SAM data include: System of National Accounts, Input-Output Tables, Household Surveys, and so on. Thus, data for the said SAM were obtained from publications of the NBS, CBN, the Federal Ministry of Agriculture and Water Resources (FMAWR) and the 1995 UNDP SAM for Nigeria (Nwafor, et al., 2010).

The IFPRI SAM was the latest and the most detailed SAM of the Nigerian economy, especially with regard to the agricultural sector as at the time of writing this paper. It is made up of 147 balanced matrix accounts comprising 61 activity sectors, 62 commodities, 3 factors of production, 12 household groups, 4 tax accounts, as well as, transaction costs, enterprises, government, saving and investment and the rest of the world accounts. Of the 61 activities, 34 are in agriculture, 12 in manufacturing 13 service sectors and 2 mining sectors.

For the purpose of achieving the objectives of the current paper, the original SAM was aggregated to one with 4 production activity sectors (food, other agriculture, crude oil, manufactures/services), 4 commodities (food, other agriculture, crude oil and manufactures/services), 2 factors of production

16 This section draws immensely from Nkang et al. (2013). Simulating the Impact of Exogenous Food Price Shock on Agriculture and the Poor in Nigeria: Results from a Computable General Equilibrium Model. Economic Analysis and Policy, Vol. 43 No 1, pp. 7994 
(labour and capital), 4 household groups (rural-south, rural-north, urban-south and urban-north), 4 tax accounts (direct tax, indirect sales tax, import tax and activity tax), government, saving and investment and the rest of the world accounts. In the end a balanced SAM of 21 square matrix accounts was obtained and used in the subsequent analysis. From the modified SAM, all the data needed for calibration of the CGE model, aside the free parameters were obtained.

\subsection{Analytical Framework}

This paper used a computable general equilibrium (CGE) model to determine the impact of an oil price shock on agriculture and households' welfare. A CGE model was used in order to generate the economy-wide (macro) impacts of the shocks on the agriculture sector, as well as, the distributional impacts on households' expenditures (used to proxy household welfare). The intuition behind this choice is that economic shocks are both idiosyncratic and covariate in nature; having economy-wide, sectoral and distributional effects and thus, are preferably studied in the context of a CGE model.

In the current framework, household categories are explicitly integrated into a CGE model via the SAM. A popular approach in this framework is the extended representative household (ERH) CGE model, which is a standard approach in general equilibrium analysis of distributional implications of economic shocks and policies (see, Cockburn, 2001; Bhasin and Obeng, 2004; Essama-Nssah, 2005). Thus, with some modifications, this study adopted the ERH approach proposed by Decaluwe, Patry, Savard and Thorbecke (1999) and Decaluwe, Savard and Thorbecke (2005) and applied widely in the context of many African countries. Consequently, instead of using one household in the model, four household groups described in the previous section were incorporated into the SAM to allow us capture the distributional impacts of the shock.

\subsection{Description of the CGE Model}

In this subsection, we describe CGE model equations by blocks without the model specification, parameters and variables in the model due to limitation of space (see notes in the appendix).

\subsubsection{Production and Factor Demand}

The model assumes that producers maximize profits subject to production functions, while households maximize utility subject to budget constraints. Furthermore, factors are mobile across activities, available in fixed supplies, and demanded by producers at market clearing prices. The model satisfies Walras' law in that the set of commodity market equilibrium 
conditions are functionally dependent, and it is homogenous of degree zero in prices. The model comprises six blocks of equations describing production and factor demand, income and savings, demand for commodities, prices, international trade as well as equilibrium and market clearing ${ }^{2}$. Without going into extensive detail, we discuss the main features of the CGE model below.

Using a CES production function for value-added, we assume that producers have a profit-maximizing behaviour which is subject to the production function. Since the production system in the model is nested, at the top level of aggregation, value-added and intermediate inputs combine in fixed proportions, via a Leontief aggregator function to produce gross sectoral output. At the next level of aggregation, value-added is a constant returns to scale constant elasticity of substitution (CES) function of labour and capital, as factors of production and intermediate inputs in Leontief technology (equations 1-3).

\subsubsection{Income and Savings}

In this model, households derive their income from three sources: primary factor (labour and capital) payments, transfers from the government and transfers from the rest of the world (remittances from abroad). Household savings is specified as a fixed proportion of household's disposable income. Government revenue is generated from direct taxes collected on household income, indirect taxes on domestic goods and production activities, and taxes levied on imports, plus dividends paid to government as well as foreign transfers to government. Government savings are obtained from the difference between government income and expenditures; made up of government consumption and transfers made to households (equations $4-16$ )

\subsubsection{Demand for Commodities}

Household expenditure is derived from maximizing the Stone-Geary linear expenditure system (LES) subject to the household's budget constraint. Household's total consumption expenditure is given by household disposable income less savings. Government demand for commodities as well as investment demand is modelled using a Cobb-Douglas utility function (equations $17-20$ ).

\section{$\underline{\text { 3.3.4 Prices }}$}

The price block of the model is given by equations $21-23$, which define the import price, export price and the consumer price index.

\section{$\underline{\text { 3.3.5 International Trade }}$}

We assume in a standard fashion that Nigeria is small open economy and thus we follow the Armington (1969) assumption of imperfect 
substitutability between domestically produced and imported goods to model import demand, using a CES function. In a similar manner, exports are modelled using a constant elasticity of transformation (CET) function, with the believe that exports are also not perfect substitutes for domestically produced goods in importing countries, thus characterising the relative facility of a producer to switch between producing for the domestic and foreign markets (equations $24-29$ ).

\subsubsection{Equilibrium, Market Clearing and Model Closures}

In this model, we ensure equilibrium in the factor markets for labour and capital, product markets for the commodities as well as balance of payments equilibrium of the foreign sector. As indicated earlier, the economy has no impact on international markets, and so takes the world prices as given. Thus, world prices of imports and exports and dividends paid to the rest of the world are exogenously fixed. The next closure condition is that the supply of labour and capital are also exogenous to the model, as are the nominal exchange rate (which is the model numeraire) and foreign savings, as well as, government savings and transfers to households. The price index is endogenous and allows for the clearing of the foreign savings (or the current account balance). The model therefore follows the classical closure, as savings is investment-driven (equations $30-35$ ).

The CGE model described above was implemented with the aid of the General Algebraic Modelling System (GAMS) software package, using CONOPT3 Solver for Non-Linear Programming (NLP). This was used because the model was specified as a system of non-linear equations with an objective function to be optimized, and in this case by maximization. Thus, the model was solved by maximizing the objective function specified in equation 35 (see appendix notes). On successfully solving the model and replicating the baseline equilibrium, the simulation experiment was carried out and the result measured against the baseline to give us the impact of the shock.

\subsection{RESULTS AND DISCUSSION}

The results of the simulation experiment of the impact of a 50 per cent drop in oil prices on agriculture and households' welfare are presented and subsequently discussed under this section. Oil prices had plummeted almost 50 per cent from about US\$115 in June 2014 to about US\$57.47 in April 2015, and even as low as US\$30.66 in January, 2016 but picked up and rallied around the US\$50 to US\$60 mark for a long time (see, CBN, 2015; Reuters, 2017, etc.). This, therefore, informed the level of our simulation experiment. The results are reported as percentage changes from baseline figures. 


\subsection{Macro Impacts}

Table 1 shows the results of the impact of a 50 per cent fall in crude oil prices on some macroeconomic aggregates. While the GDP records a 7.036 per cent increase, aggregate household income, aggregate government income and total savings all fell by $0.870,7.317$ and 86.300 per cent respectively. Theoretically, the impact of a fall in oil price on the GDP of a net oil exporting country is at best mixed. Some studies (see for example, Umar and Abdulhakeem, 2010; Cantore, et al., 2012) have shown that real GDP tends to rise with short-term increase in oil prices and vice versa. However, others (see,; Moshiri and Banihashem, 2011; Cantore, et al., 2012) are of the view that oil prices do not significantly slow down the pace of economic growth since the main transmission mechanism of oil price changes in net oil-exporting countries is through government revenues and expenditure. Further than these, while governments in net oil-exporting countries are wont to pursue expansionary fiscal policies during periods of high oil prices, they find it difficult to adopt fiscal austerity at times of falling oil prices, as they resort to other means (like depleting their savings and borrowing) to boost government revenues, maintain budgetary expenditures and bolster economic activity. This may substantially explain the result of the impact of the shock on GDP.

Following the shock, the fall in aggregate household income, government income and total savings is as expected. But particularly remarkable is the plunge in savings, which in fact corroborates the earlier assertion that oil-exporting countries would in the event of a fall in oil revenues deplete savings and borrow to finance expenditures instead of pursuing fiscal austerity measures. In the wake of the 2014 oil price shock and the accompanying drop in government fiscal revenues, the federal government have had to draw from the excess crude account (ECA) and borrow more from both domestic and foreign sources to finance budgetary expenditures.

Table 1: Macro Results

\begin{tabular}{|c|c|c|}
\hline Variable & Base Solution & $\begin{array}{c}\text { Percentage Change from } \\
\text { Base Level }\end{array}$ \\
\hline & \multicolumn{2}{|c|}{ N'Million } \\
\hline Gross Domestic Product (GDP) & 20835543.605 & 7.036 \\
\hline Aggregate Household Income & 15453200.000 & -0.870 \\
\hline Aggregate Government Income & 5767877.010 & -7.317 \\
\hline Total Savings & 976108.977 & -86.300 \\
\hline
\end{tabular}

Source: CGE Model Simulation Results

\subsection{Sectoral Impacts}

For the sectoral impacts (see, Table 2), we distinguish the food sector from other agriculture to see if the impact of an oil price shock would be more severe on that subsector than in other agriculture. A drop in the world price of crude by 50 per cent raises domestic output of food and other agriculture by 
6.339 and 30.175 per cent, respectively. This result is as expected because a fall in the price of oil puts pressure on the external reserves and the exchange rate, thus forcing it to depreciate. Accordingly, a real depreciation makes exports cheaper and bolsters domestic output growth especially in commodities where the country has comparative resource advantage in production. This thus raises capital factor demand by 50.864 per cent in food and 83.383 per cent in other agriculture. As our agricultural exports become more competitive, resource allocation is altered and more capital is employed in the agricultural sector to boost output for both the home market and exports. However, labour demand in the food sector drops by -14.828 per cent while it goes up by 3.532 per cent in other agriculture. This suggests a shift in labour resources out of the food sector, which may be as result of use of capital to increase output probably because of improvements in value chains, etc.

The results of the domestic production for the home market (which by definition is the quantity of gross domestic production minus exports) are similar to those of gross domestic output. Of particular note, however, is the increase in the level of domestic production of crude oil to the home market as a result of depressed prices at the international market. The increase in gross domestic output causes prices in food and other agriculture to fall by 6.910 and 5.612 per cent respectively. These results are theoretically plausible, as data from the NBS (2015c) shows that food price inflation had dropped from 9.78 per cent in June 2014 to 9.21 per cent in January 2015 when oil price fell from about $\$ 114.17$ to $\$ 48.60$ respectively. Also, worth mentioning is the 32.589 per cent fall in the domestic price of crude oil, which is in line with the reduction in pump price (in January 2015) of crude oil products in the buildup of the fall in oil prices in the international market.

Domestic sales of food and other agricultural composites (made up of domestic production to home market and imports) increased by 1.878 and 12.616 per cent respectively. Clearly, looking at the results for imports in these two sectors, it is safe to conclude that the increase was driven mainly by the high margin of increase in the domestic production to home market rather than imports. This also explains the fall in the price of food and other agricultural composites.

The simulated 50 per cent fall in oil prices substantially reduced imports in food and other agriculture sectors by 41.309 and 33.211 per cent respectively. However, exports in the two sectors increased by 92.361 and 129.050 per cent in that order. The direction of response of both imports and exports to a fall in oil price conforms to a priori expectations and conventional wisdom, while the magnitude of the change is especially informative. Dwindling accretion to the external reserves due to falling oil prices had led to a worsening of net foreign assets position, triggering an exchange rate crisis leading to a substantial depreciation of the naira-dollar exchange rate. 
Theoretically, this bolsters domestic production, discouraging imports and increasing exports as seen in the results of imports and exports in food and other agriculture sectors.

Data from the CBN (2015) shows that sectoral utilization of foreign exchange for visible imports fell from US\$17.57 billion during the JulyDecember 2014 period to US\$13.72 billion during the January-June 2015 period, as the exchange rate depreciated from an average of 157.29 /US $\$$ in June 2014 to an average of $\$ 197.08 / U S \$$ in June 2015. By January-June 2016 period, sectoral utilization of foreign exchange for visible imports further dropped to US\$8.85 billion, while the exchange rate had depreciated to about 258/US\$ in June 2016 following the introduction of a more flexible exchange rate regime by the Central Bank of Nigeria. From these results, a fall in oil price is not necessarily bad for agriculture, as it appears to be a boost to both local production and export supply.

Table 2: Sectoral Results

\begin{tabular}{|c|c|c|}
\hline Variable & Base Solution & $\begin{array}{l}\text { Percentage Change } \\
\text { from Base Level }\end{array}$ \\
\hline & & $50 \%$ Fall in Oil Prices \\
\hline Gross Domestic Output & \multicolumn{2}{|c|}{ N'Million } \\
\hline Food & 6456533.705 & 6.339 \\
\hline Other Agriculture & 549607.186 & 30.175 \\
\hline Crude Oil & 745559.864 & 0.570 \\
\hline Manufactures/Services & 13083842.85 & 32.723 \\
\hline Domestic Production to Home market & \multicolumn{2}{|c|}{ N'Million } \\
\hline Food & 6451123.349 & 6.254 \\
\hline Other Agriculture & 520779.206 & 23.685 \\
\hline Crude Oil & 118662.781 & 34.457 \\
\hline Manufactures/Services & 12618307.4 & 25.994 \\
\hline Domestic Sales of Composite commodity & \multicolumn{2}{|c|}{ N'Million } \\
\hline Food & 7019982.205 & 1.878 \\
\hline Other Agriculture & 629509.364 & 12.616 \\
\hline Crude Oil & 120016.425 & 32.732 \\
\hline Manufactures/Services & 17151628.25 & 2.652 \\
\hline Imports & \multicolumn{2}{|c|}{ N'Million } \\
\hline Food & 375861.240 & -41.309 \\
\hline Other Agriculture & 99233.417 & -33.211 \\
\hline Crude Oil & 1353.644 & -93.916 \\
\hline Manufactures/Services & 4490615.278 & -56.382 \\
\hline Exports & \multicolumn{2}{|c|}{ N'Million } \\
\hline Food & 5410.356 & 92.361 \\
\hline Other Agriculture & 28827.980 & 129.050 \\
\hline Crude Oil & 7336897.083 & 0.000 \\
\hline Manufactures/Services & 465535.454 & 194.371 \\
\hline Factor Demand (Capital) & \multicolumn{2}{|c|}{ ॠ'Million } \\
\hline Food & 2235632.720 & 50.864 \\
\hline Other Agriculture & 166128.654 & 83.383 \\
\hline
\end{tabular}




\begin{tabular}{|c|c|c|}
\hline Crude Oil & 6841676.980 & 0.789 \\
\hline Manufactures/Services & 1565438.960 & 156.435 \\
\hline Factor Demand (Labour) & \multicolumn{2}{|c|}{ N'Million } \\
\hline Food & 3280392.103 & -14.828 \\
\hline Other Agriculture & 231495.882 & 3.532 \\
\hline Crude Oil & 18713.492 & -57.245 \\
\hline Manufactures/Services & 5569053.743 & 8.780 \\
\hline \multicolumn{3}{|c|}{ Price of Domestic Output } \\
\hline Food & 1.000 & -6.910 \\
\hline Other Agriculture & 1.000 & -5.612 \\
\hline Crude Oil & 1.000 & -37.309 \\
\hline Manufactures/Services & 1.000 & 2.596 \\
\hline \multicolumn{3}{|c|}{ Price of Domestic Output to Home Market } \\
\hline Food & 1.000 & -6.947 \\
\hline Other Agriculture & 1.000 & -7.995 \\
\hline Crude Oil & 1.000 & -32.589 \\
\hline Manufactures/Services & 1.000 & 1.270 \\
\hline \multicolumn{3}{|c|}{ Price of Composite Commodities } \\
\hline Food & 1.000 & -4.969 \\
\hline Other Agriculture & 1.000 & -3.579 \\
\hline Crude Oil & 1.000 & -32.413 \\
\hline Manufactures/Services & 1.000 & 5.506 \\
\hline
\end{tabular}

Source: CGE Model Simulation Results

\subsection{Distributional Impacts}

Table 3 shows the results of the impact of a 50 per cent fall in oil prices on households' income and expenditure. The shock causes households' disposable income and expenditure to fall except in urban north households. Rural households were the most affected by this shock, as rural north households' expenditure fell by 6.543 per cent while rural south households registered a moderate fall in their expenditures by 1.401 per cent. Furthermore, urban south households' expenditures dropped marginally by 0.759 per cent whereas the shock actually caused the expenditure of urban north households to increase by a significant 4.662 per cent. The results clearly indicate that rural households suffer more from this shock, while some urban households could actually benefit from it. Specifically, rural north households suffer the impact of a fall in oil prices most, while urban north households benefit the most from the shock. Urban south households seemed to be impacted the least by a 50 per cent fall in world price of crude oil.

Conceptually, the impact of an oil price shock on households in Nigeria (as a net oil exporter) with an enclave oil sector is indirect. This trickles down from the macroeconomic repercussions of the shock and from the government expenditure channels (which include inflation, transfers, spending on services, employment, etc.) as well as via exchange rate depreciation in an attempt to restore balance of payments equilibrium. Given this background, the 
distributional impacts recorded above would have been determined by various factors acting together, which include the sources and uses of household incomes.

According to the SAM data, while the urban households received direct transfers from government, rural households did not. Again, the increase in the expenditure of urban north households could be explained by the fact that almost 70 per cent of their earnings came from wage (labour) income, which could have been switched into the production of local import substitutes as exports become cheaper and imports more expensive following a real depreciation of the exchange rate. Moreover, a fall in government revenue following oil price decline might tend to affect rural north households most because financing of rural projects that benefited rural north households might have been hampered in spite of the fact that government might continue to fund projects in the urban areas even in the face of fiscal austerity.

Table 3: Impact on Households' Incomes and Expenditures

\begin{tabular}{|c|c|c|}
\hline Variable & Base Solution & $\begin{array}{c}\text { Percentage Change from } \\
\text { Base Level }\end{array}$ \\
\hline & & $\mathbf{5 0 \%}$ Fall in Oil Prices \\
\hline Household Disposable income & N'million & -1.401 \\
\hline Rural south & 2642927.340 & -6.543 \\
\hline Rural north & 3646169.671 & -0.759 \\
\hline Urban south & 5288615.606 & 4.715 \\
\hline Urban north & 3875486.962 & \\
\hline $\begin{array}{c}\text { Household consumption } \\
\text { expenditure }\end{array}$ & & -1.401 \\
\hline Rural south & 2631340.864 & -6.543 \\
\hline Rural north & 3598827.408 & -0.747 \\
\hline Urban south & 3597972.672 & 4.662 \\
\hline Urban north & 2959873.227 & -1.912 \\
\hline Minimum Consumption (All) & 12581493.448 & \\
\hline
\end{tabular}

Source: CGE Model Simulation Results

\subsection{CONCLUSION AND POLICY IMPLICATIONS}

The paper simulated the impact of a 50 per cent fall in world oil prices on agriculture and household welfare in Nigeria. From the macro results, GDP recorded a significant increase, while aggregate government income, households' income and total savings all recorded a decline. Sectoral results show that gross domestic output and supply of composites in the food and other agriculture sectors increased substantially forcing prices in the two agriculture sectors to decline. Moreover, while there was an increase in capital demand in the agricultural sector following the shock, there was however a fall in labour demand in the food sector although same went up in the other agriculture sector. The shock also caused Imports in food and other agriculture sectors to fall substantially, while there was a dramatic rise in exports in the two sectors. In terms of distributional impacts, there was a drop in incomes/expenditure in 
all households except urban north households that recorded an increase. Furthermore, rural north households were the most negatively affected, whereas urban south households were the least affected by the shock.

The implications of these results are that while high oil prices may lead to increased revenue for government in Nigeria, to the neglect of the other productive sectors of the economy, lower oil prices may not necessarily lead to output losses but could actually boost output from other sectors and lead to diversification of the export base, even with lower accretion of foreign exchange earnings in the near term. Thus an oil price fall is not necessarily detrimental, particularly as it makes exports cheaper and imports costlier hence leading to increased production of import substitutes. There is therefore the need to reduce government's reliance on oil revenue, and for boosting our net foreign assets (NFA) position. The results have shown that with falling oil price, food, other agriculture, and manufactures/services sectors show huge potential to generate foreign exchange earnings through exports. This potential should therefore be exploited. Furthermore, the implication of the distributional impacts is that targeted interventions would prove more effective in mitigating the negative impact of oil price shocks than general palliative measures as some household groups and segments of the population are affected more than others. On the whole, rural north households need the most attention based on the results of this study.

\section{NOTES}

1. The interested reader may request for the model specification and GAMS code for details on the model structure.

2. The model specification draws extensively from the Economic Modelling (ECOMOD) Network model for a small open economy.

\section{References:}

1. Adeniyi, O. A., Oyinlola, A. and Omisakin, O. A. (2011). "Oil Price Shocks and Economic Growth in Nigeria: Are Thresholds important?" OPEC Energy Review. Vol. 35. No. 4 pp. 308-333.

2. Akinleye, S. O. and Ekpo, S. (2013). "Oil Price Shocks and Macroeconomic Performance in Nigeria." Mexican Economy New Era. Vol. 2. pp. 565-624

3. Akpan, E. O. (2009). "Oil Resource Management and Food Insecurity in Nigeria." Paper Presented at the European Report on Development (ERD) Conference in Accra, Ghana, 21st-23rd May

4. Alley, I., Asekomeh, A., Mobolaji, H. And Adeniran, Y. A. (2014). "Oil Price Shocks And Nigerian Economic Growth." European Scientific Journal. Vol.10. No.19 pp. 375-391 
5. Berument, H., Ceylan, N. B. and Dogan, N. (2010). "The Impact of Oil Price Shocks on the Economic Growth of Selected MENA Countries." The Energy Journal. Vol. 31. No. 1 pp. 150-176.

6. Bhasin, V. K and Obeng, C. K. (2004). "Trade Liberalization, Foreign Borrowing, Poverty and Income Distribution of Households in Ghana." www.ecomod.net/conferences/ecomod2005/ecomod2005_Papers/623. doc

7. Binuomote S. O. and Odeniyi, K. A. (2013). "Effect of Crude Oil Price on Agricultural Productivity in Nigeria (1981-2010)." International Journal of Applied Agricultural and Apicultural Research. Vol. 9. No.1\&2 pp.131-139.

8. Cashin, P. and Patillo, C. (2000). "Terms of Trade Shocks in Africa: Are they Short-lived or Long-lived?" Working Paper, WP/00/72, IMF, Washington DC

9. Cantore, N., Antimiani, A. and Anciaes, R. A. (2012). "Energy price shocks: Sweet and Sour Consequences for Developing countries." Working Paper 355, Overseas Development Institute (ODI)

10. CBN (2015). Sectoral Utilization of Foreign Exchange. Trade and Exchange Department, Central Bank of Nigeria.

11. Coffman, M., Surles, T. and Konan, D. (2007). "Analysis of the Impact of Petroleum Prices on the State of Hawaii's Economy." Paper Prepared for State of Hawaii Department of Business, Economic Development and Tourism by University of Hawaii.

12. Cockburn, J. (2001). "Trade Liberalization and Poverty in Nepal: A CGE Micro Simulation Analysis." Discussion Paper 01-18, CRIFA.

13. Decaluwe, B., Patry, A., Savard, L. and Thorbecke, E. (1999). "Poverty Analysis within a General Equilibrium Framework." CREFA Working Paper 99-09, Department of Economics, University of Laval, Quebec, Canada.

14. Decaluwé, B, Savard, L. and Thorbecke, E. (2005). "General Equilibrium Approach for Analysis with an Application to Cameroon." African Development Review. Vol.17 pp. 213-43.

15. Essama-Nssah, B. (2005). "Simulating the Poverty Impact of Macroeconomic Shocks and Policies." World Bank Policy Research Working Paper 3788, Washington, DC.

16. Essama-Nssah, Go, Kearney, Korman, Robinson, and Thierfelder, (2008). "Economy-wide and Distributional Impact of an Oil Price Shock on the South African Economy." Policy Research Working Paper 4354, The World Bank.

17. Hamilton, J.D.(1996). "This is what Happened to the Oil PriceMacroeconomy Relationship." Journal of Monetary Economics. Vol. 38 pp. 215-220. 
18. Ikram, H. and Waqas, M (2014). "Crude Oil Price and Agriculture Productivity Growth in Pakistan." World Applied Sciences Journal. Vol. 32. No. 4. pp. 642-649

19. Iwayemi, A. and Fowowe, B. (2010). "Impact of oil price shocks on selected macroeconomic variables in Nigeria." Energy Policy. Vol. 39 pp. 603-612

20. Jiménez-Rodríguez, R. and Sánchez, M. (2005). “Oil Price Shocks and Real GDP Growth: Empirical Evidence for Some OECD Countries”, Applied Economics. Vol. 37, pp. 201-228.

21. Mondi, A., Koo, C.M. and Kim, W.J. (2011) "Oil Shocks and the World Rice Market Puzzle: A Structural VAR Analysis." Journal of the Korean Economy Vol. 12 pp. 281-325.

22. Mordi, C. N. and Adebiyi, M. A. 2010. "The Asymmetric Effects of Oil Price Shocks on Output and Prices in Nigeria using a Structural VAR Model." Central Bank of Nigeria Economic and Financial Review. Vol. 48. No. 1 pp. 1-32

23. Moshiri, S. and Banihashem, A. (2011) "Asymmetric Effects of Oil Price Shocks on Economic Growth in Oil-exporting Countries." Paper Presented at the 34th IAEE Conference, 19-23 Stockholm, June.

24. NBS (2015a) Nigerian Gross Domestic Product Report, Quarter Two, 2015. Abuja: National Bureau of Statistics (NBS)

25. NBS (2015b) Foreign Trade Statistics, Quarter Two, 2015. Abuja: National Bureau of Statistics (NBS)

26. NBS (2015c) CPI and Inflation Report, July, 2015. Abuja: National Bureau of Statistics (NBS)

27. Nkang, N. M., Omonona, B. T., Yusuf, S. A. and Oni, O. A. (2013). Simulating the Impact of Exogenous Food Price Shock on Agriculture and the Poor in Nigeria: Results from a Computable General Equilibrium Model. Economic Analysis and Policy, Vol. 43 No 1, pp. 79-94

28. Nwafor, M., Diao, X. and Alpuerto, V. (2010). “A Social Accounting Matrix for Nigeria: Methodology and Results." Nigeria Strategy Support Program (NSSP) Report No. NSSP007, International Food Policy Research Institute, Washington, DC

29. Olomola, P. A. and Adejumo, A.V. (2006), "Oil Price Shock and Macroeconomic Activity in Nigeria." International Research Journal of Finance and Economics. Vol. 3. pp. 28-34.

30. Olusegun, O. A. (2008). "Oil Price Shocks and the Nigerian Economy: A Forecast Error Variance Decomposition Analysis." Journal of Economic Theory. Vol. 2. No. 4 pp. 124-130

31. OPEC (2015). Monthly Oil Market Report, July 2015. Vienna: Organization of the Petroleum Exporting Countries 
32. Rasche, R. H. and Tatom, J. A. (1977). "The Effects of the New Energy Regime on Economic Capacity, Production and Prices." Federal Reserve Bank of St. Louis Review. Vol. 59. No. 4 pp. 2-12.

33. Sturm, M., Gurtner, F. and Alegre, J.G. (2009). "Fiscal Policy Challenges in Oil-exporting Countries - A Review of Key Issues." Occasional Paper 104. Frankfurt: European Central Bank.

34. Thomas, A., Mühleisen, M. and Pant, M. (2010). "Peaks, Spikes, and Barrels: Modelling Sharp Movements in Oil Prices." IMF Working Paper, No. 186. Strategy, Policy, and Review Department

35. Udoh, E. and Egwaikhide, F. O (2012). "Does International Oil Price Volatility Complement Domestic Food Price Instability in Nigeria? An Empirical Enquiry." International Journal of Economics and Finance. Vol. 4, No. 1 pp. 235-246.

36. Umar, G. and Kilishi, A. A. (2010). "Oil Price Shocks and the Nigeria Economy: A Variance Autoregressive (VAR) Model.” International Journal of Business and Management Vol. 5, No. 8 pp. 39-49

37. Varangis, P., Varma, S., dePlaa, A. and Nehru, V. (2004). "Exogenous Shocks in Low Income Countries: Economic Policy Issues and the Role of the International Community." Paper Prepared for the Report: Managing the Debt Risk of Exogenous Shocks in Low Income Countries. The World Bank, Washington DC 